\title{
Stopped-flow kinetic study of the peroxidase reactions of mangano-microperoxidase-8
}

Received: 10 April 2001 / Accepted: 3 June 2001 / Published online: 27 July 2001

(C) SBIC 2001

\begin{abstract}
We have investigated the kinetics for the peroxidase-type reaction of mangano microperoxidase 8 (Mn(III)-MP8) by the time-resolved and single-wavelength stopped-flow technique. The formation of intermediate and its subsequent reaction with substrates were studied separately. Oxidation of $\mathrm{Mn}$ (III)-MP8 by $\mathrm{H}_{2} \mathrm{O}_{2}$ at $\mathrm{pH} 10.7$ yields an intermediate (1) with a rate constant of $2.9 \times 10^{4} \mathrm{M}^{-1} \mathrm{~s}^{-1}$. The formation of 1 exhibits no deuterium solvent isotope effect, favoring the homolytic cleavage of the Mn(III)-MP8 bound hydroperoxide. The rate for the formation of 1 increases sharply as the $\mathrm{pH}$ increases and no other intermediate was detected in the entire $\mathrm{pH}$ range. Addition of substrate to 1 leads to the regeneration of $\mathrm{Mn}(\mathrm{III})-\mathrm{MP} 8$. Monitoring the conversion of 1 to Mn(III)-MP8 allows the determination of the substrate reactivity. The substrate reactivity varies by more than two orders of magnitude ranging from $1.04 \times 10^{6} \mathrm{M}^{-1} \mathrm{~s}^{-1}$ for ascorbic acid to $4.61 \times 10^{3} \mathrm{M}^{-1} \mathrm{~s}^{-1}$ for aniline. It is linearly correlated with the reduction potential for most of the substrates studied, with the easier oxidized species showing greater reactivity. The substrate reactivity drops rapidly as the $\mathrm{pH}$ increases. The substrate reactivity at $\mathrm{pH} 10.7$ for the Mn(III)-MP8 system is smaller than that of the corresponding Fe(III)MP8 system by 2- to 25-fold, depending on the substrate used.
\end{abstract}

Keywords Mn(III)-microperoxidase $8 \cdot$ Kinetic study · Substrate reactivity

H.-C. Yeh · C.-H. Yu · Y.O. Su · W.-Y. Lin $(\bowtie)$

Department of Chemistry, National Taiwan University,

Taipei, 106, Taiwan, ROC

E-mail: wylin@ccms.ntu.edu.tw

J.-S. Wang

School of Medicine, Fu-Jen Catholic University,

Hsin-Chuang 242, Taiwan, ROC

S.-T. Chen

Institute of Biological Chemistry, Academia Sinica,

Taipei 115, Taiwan, ROC

\section{List of abbreviations}

Fe(III)-MP8 Ferric Microperoxidase 8

Mn(III)-MP8 Mangano Microperoxidase 8

OMP

o-Methoxyphenol

\section{Introduction}

Numerous metalloporphyrin model compounds have been designed to mimic the biological functions of a variety of heme-containing enzymes $[1,2,3]$. The functional diversity of the heme enzymes is closely related to the proximal ligand of iron(III) and the protein environment. The proximal ligands of iron in horseradish peroxidase (HRP), catalase, and cytochrome P-450 are histidine, tyrosine, and cysteine, respectively. The electron donation from the imidazolate, tyrosinate, or cysteinate to the iron(III) facilitates the formation of high-valent iron species, which are the key intermediates for the subsequent catalytic reaction. An attractive heme model compound is iron(III)-containing microperoxidase 8 (Fe(III)-MP8) obtained from proteolytic digestion of cytochrome $c$ with pepsin and trypsin [4]. Fe(III)-MP8 contains a covalently linked octapeptide with a histidine imidazole acting as the axial ligand of iron. The sixth coordination site is occupied by water at $\mathrm{pH}$ below 9 and is easily replaced by the oxidant to initiate the catalytic reaction. The open active site enables Fe(III)-MP8 to catalyze a variety of reactions such as peroxidase $[5,6,7,8]$, cytochrome P450 $[9,10]$, and chloroperoxidase $[11,12]$ types of reactions. It also undergoes less aggregation than other porphyrin models in aqueous solution [13].

The peroxidase-type reaction of Fe(III)-MP8 has been extensively studied. The proposed mechanism usually involves high-valent iron-oxo intermediates, analogous with compounds I and II of HRP [14, 15]. However, these highly reactive intermediates may undergo degradation, especially in the absence of a reductant (substrate) and/or in the presence of high concentration of 
oxidant. As a result, the exact nature of the intermediates has not been clearly characterized. The limited operational stability of iron-porphyrin compounds is well known [16]. Many manganese-porphyrins, which are less reactive (and perhaps undergo less degradation) than their iron counterparts [17, 18], have been frequently employed to help elucidate the catalytic mechanism. However, only very few studies on manganese-containing MP8 (Mn(III)-MP8) have been reported. Primus and coworkers have shown that Mn(III)-MP8 exhibits both peroxidase- and P450-like reactivities [19]. They proposed a mechanism with three reactive species (compounds I, II, and MP8-hydroperoxide complex) to explain their kinetic results. Yet there was no spectroscopic evidence for the existence of these intermediates. Moreover, most kinetic studies were carried out at high concentration of oxidant (e.g., $\mathrm{H}_{2} \mathrm{O}_{2}$ ). This may lead to degradation of microperoxidase, occurrence of multiple turnovers, and formation of product mixtures, which will complicate the interpretation of the kinetic data.

In this paper we have investigated the kinetics for the formation of the intermediate from the reaction of $\mathrm{Mn}$ (III)-MP8 and $\mathrm{H}_{2} \mathrm{O}_{2}$ and the subsequent reaction of the intermediate with various electron-donating substrates by the stopped-flow technique using the timeresolved and the single-wavelength modes. Relative low concentration of $\mathrm{H}_{2} \mathrm{O}_{2}$ (a few $\mu \mathrm{mol} \mathrm{l}^{-1}$ ) has been employed to minimize the degradation of the intermediate and the chance of multiple turnovers. We have also examined the $\mathrm{pH}$ dependence of the kinetic constants for the formation of the intermediate and its subsequent reaction with substrate. The kinetic results were then compared with those of Fe(III)-MP8 in the previous study [20].

\section{Materials and methods}

\section{Materials}

Horse heart cyctochrome $c$, tris(hydroxymethyl) aminomethane (Tris), pepsin, and trypsin were purchased from Sigma (USA). 1Naphthol, $o$-methoxyphenol, and 2,2'-azinobis(3-ethylbenzothiazoline-6-sulfonic acid) (ABTS) were obtained from Aldrich (USA). p-Anisidine, 4-methoxyphenol, homovanillic acid, sodium carbonate, sodium phosphate, sodium hydrogen phosphate, and deuterium oxide were from Acros Organics (Belgium). Sodium chloride and phenol were obtained from Merck (Germany) and potassium ferrocyanide from Kanto Chemical Co. Inc., (Japan). $\mathrm{Fe}$ (III)-MP8 was prepared from the proteolytic digestion of cytochrome $c$ with pepsin and trypsin [4]. Mn(III)-MP8 was synthesized by the procedure in the literature [21]. The oxidation potentials of the substrates were determined in the previous study [20].

\section{Stopped-flow measurements}

The stopped-flow experiments were performed on a Hitech SF-61 stopped-flow instrument (Hitech Scientific, UK) equipped with a sample handling unit (SHU-61), a photodiode array assembly (MG-6010), a 75-W xenon lamp, and a circulating water bath for temperature control. It can be operated in either the absorption or the fluorescence mode. For measuring the rate of formation of the intermediate, change in absorbance (at 368 or $404 \mathrm{~nm}$ ) was monitored continuously after the mixing of $\mathrm{Mn}(\mathrm{III})-\mathrm{MP} 8$ and $\mathrm{H}_{2} \mathrm{O}_{2}$, which were stored in two separate syringes. For measuring the rate for the reaction of intermediate with substrate, Mn(III)-MP8 and $\mathrm{H}_{2} \mathrm{O}_{2}$ were premixed in one syringe and the substrate was stored in the other. After an appropriate delay time $(\sim 30 \mathrm{~s})$ to attain a maximum amount of intermediate, the two solutions were mixed and the changes in absorbance (or fluorescence) were recorded continuously. All the experiments were carried out at $25^{\circ} \mathrm{C}$. The built-in software of the stopped-flow instrument allows multiexponential fitting of the traces. In operating at different $\mathrm{pH}$ ranges, the following buffers ( $10 \mathrm{mmol}^{-1}$ each) were employed and adjusted with $\mathrm{HCl}$ or $\mathrm{NaOH}$ to the desired $\mathrm{pH}$ : sodium hydrogen phosphate ( $\mathrm{pH} 7-8.3)$, Tris $(\mathrm{pH} 8.3-9.3)$, sodium carbonate (pH 9.3-11.3), sodium phosphate ( $\mathrm{pH} 11.3-13)$. For the experiments of deuterium solvent isotope effect, sodium carbonate was used as the buffer and the $\mathrm{pL}(\mathrm{pH}$ or $\mathrm{pD}$ ) was adjusted to 10.7. The relation $\mathrm{pD}=\mathrm{pH}$ meter reading +0.4 was employed in the determination of $\mathrm{pD}$ with the $\mathrm{pH}$ meter [22]. For each kinetic analysis, at least ten replicate measurements were performed and the relative standard deviation for the obtained rate constants was $3 \sim 4 \%$.

\section{Results}

\section{Formation of intermediates}

Microperoxidase exhibits much larger peroxidase activity (by around two orders of magnitude in terms of $\mathrm{k}_{\text {cat }}$ / $\mathrm{K}_{\mathrm{M}}$ [23]) than its $\mathrm{P} 450$ and catalase activity. Therefore the last two types of reactions are ignored in treating the kinetics of peroxidase reaction. Figure 1 shows the stopped-flow time-resolved absorption spectra for the oxidation of $\mathrm{Mn}(\mathrm{III})-\mathrm{MP} 8$ by $\mathrm{H}_{2} \mathrm{O}_{2}$ at $\mathrm{pH}$ 10.7. Oxidation of $\mathrm{Mn}(\mathrm{III})$-MP8 with $\mathrm{H}_{2} \mathrm{O}_{2}$ results in a gradual disappearance of the absorption bands at 368 and $464 \mathrm{~nm}$ and the concomitant appearance of a new peak at $404 \mathrm{~nm}$. Sharp isosbestic points at 389 and $418 \mathrm{~nm}$ were also observed indicating the direct conversion of Mn(III)-MP8 to an intermediate (called $\underline{1}$ ). The process can be described as

$\mathrm{Mn}(\mathrm{III})-\mathrm{MP} 8+\mathrm{H}_{2} \mathrm{O}_{2} \stackrel{\mathrm{k}_{1}}{\longrightarrow} \underline{1}$

The rate of the formation of 1 is given by

Rate $=\mathrm{k}_{1}[\mathrm{Mn}(\mathrm{III})-\mathrm{MP} 8]\left[\mathrm{H}_{2} \mathrm{O}_{2}\right]$

Quantitative formation of 1 at $\mathrm{pH} 10.7$ was obtained with 10 molar excess of $\mathrm{H}_{2} \mathrm{O}_{2}$ to $\mathrm{Mn}$ (III)-MP8 (data not shown). The changes in molar absorptivities $(\Delta \epsilon)$ for the conversion of Mn(III)MP-8 to 1 at 368 and $404 \mathrm{~nm}$ are $5.05 \times 10^{4}$ and $8.68 \times 10^{4} \mathrm{M}^{-1} \mathrm{~cm}^{-1}$, respectively. These values will be used to estimate the concentration of 1 during the reaction.

Typical stopped-flow time courses for the changes in absorbance at 368 and $404 \mathrm{~nm}$ are shown in Fig. $1 \mathrm{~b}$. Analysis of the traces allows the determination of the rate constant $\mathrm{k}_{1}$ by the method of initial rate. Computer simulation of the traces yields the initial slopes, which are then plotted against $\left[\mathrm{H}_{2} \mathrm{O}_{2}\right]$ as illustrated in Fig. 2 . Both plots are linear, in accord with Eq. (2). The slopes $\left(=\mathrm{k}_{1}[\mathrm{Mn}(\mathrm{III})-\mathrm{MP} 8]_{\mathrm{o}} \Delta \epsilon\right)$ yield $\mathrm{k}_{1}=2.6 \times 10^{4} \mathrm{M}^{-1} \mathrm{~s}^{-1}$ at 


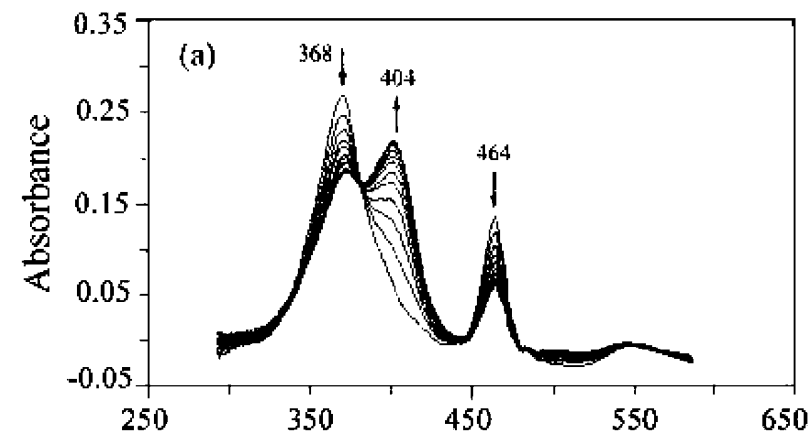

Wavelength $/ \mathrm{nm}$

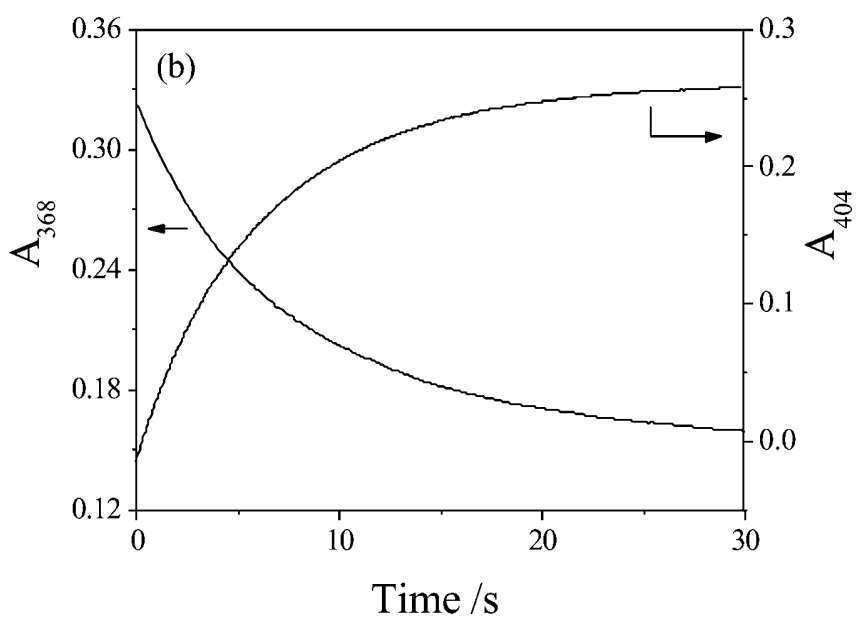

Fig. 1 a Stopped-flow time-resolved absorption spectra $(2.5 \mathrm{~s}$ per trace). b Time courses of the changes in absorbance (at 368 or $404 \mathrm{~nm}$ ) for the oxidation of $\mathrm{Mn}(\mathrm{III})-\mathrm{MP} 8\left(4 \mu \mathrm{mol} \mathrm{l}^{-1}\right)$ with $\mathrm{H}_{2} \mathrm{O}_{2}$ $\left(4 \mu \mathrm{mol}{ }^{-1}\right)$ at $\mathrm{pH} 10.7$

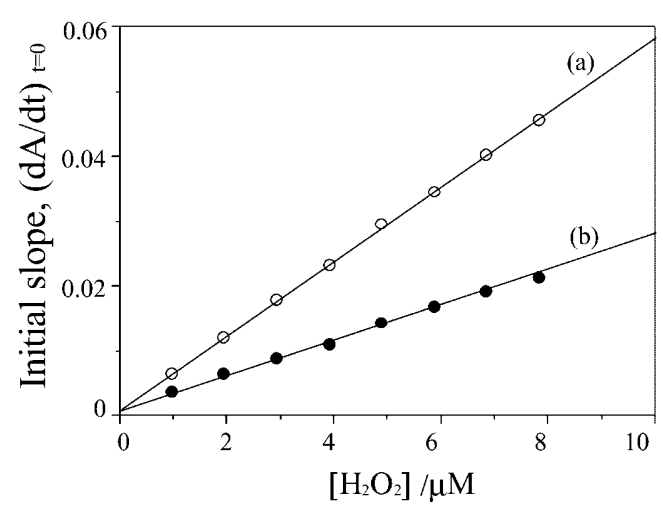

Fig. 2 Plots of the initial slopes, monitored at: a $404 \mathrm{~nm}$; b $368 \mathrm{~nm}$, as a function of $\left[\mathrm{H}_{2} \mathrm{O}_{2}\right]$ for the oxidation of $\mathrm{Mn}$ (III)-MP8 $\left(4 \mu \mathrm{mol} 1^{-1}\right)$ with $\mathrm{H}_{2} \mathrm{O}_{2}$ at $\mathrm{pH} 10.7$

$368 \mathrm{~nm}$ and $3.2 \times 10^{4} \mathrm{M}^{-1} \mathrm{~s}^{-1}$ at $404 \mathrm{~nm}$, in good agreement with each other. The average value of $\mathrm{k}_{1}$ is $2.9 \times 10^{4} \mathrm{M}^{-1} \mathrm{~s}^{-1}$.

\section{Reaction of intermediate with substrate}

Addition of the substrate, $o$-methoxyphenol (OMP), to 1 leads to the regeneration of Mn(III)-MP8 as revealed by

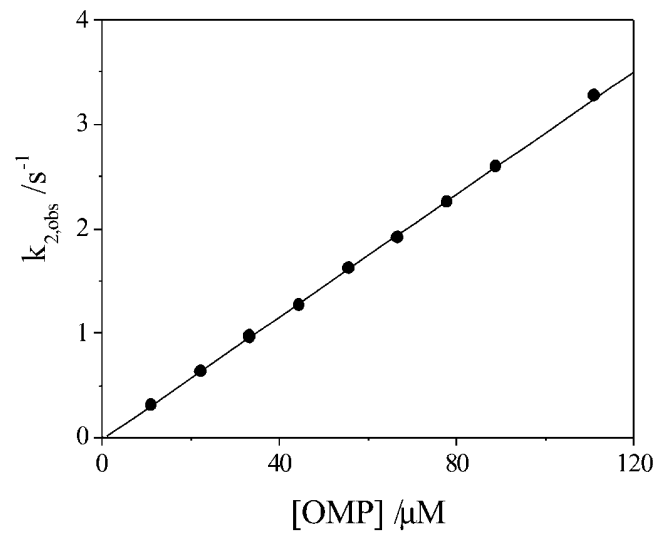

Fig. 3 Plot of $\mathrm{k}_{2 \text {,obs }}$ vs the concentration of OMP at $\mathrm{pH} 10.7$. Intermediate produced by mixing Mn(III)-MP8 $\left(2.28 \mu \mathrm{mol}^{-1}\right)$ and $\mathrm{H}_{2} \mathrm{O}_{2}\left(1.96 \mu \mathrm{mol} \mathrm{l}^{-1}\right)$ was allowed to react with various concentrations of OMP to yield different values of $\mathrm{k}_{2, \mathrm{obs}}$

a gradual disappearance of the band at $404 \mathrm{~nm}$ for 1 and a concomitant appearance of the bands at 368 and $464 \mathrm{~nm}$ for Mn(III)-MP8 (data not shown). The recovery of $\mathrm{Mn}(\mathrm{III})-\mathrm{MP} 8$ is $90-95 \%$ indicating that the degradation of $\mathrm{Mn}(\mathrm{III})$-MP8 is insignificant. This process is expressed as

$\underline{1} \stackrel{\mathrm{k}_{2}[\mathrm{~S}]}{\longrightarrow} \mathrm{Mn}(\mathrm{III})-\mathrm{MP} 8$

where $[\mathrm{S}]$ is the concentration of substrate, which is usually much greater than that of 1 and is assumed to be unchanged during the reaction. The time variation of the absorbance is given by

$\mathrm{A}=\mathrm{a}+\mathrm{b} \exp \left(-\mathrm{k}_{2}[\mathrm{~S}] \mathrm{t}\right)$

where $\mathrm{a}$ and $\mathrm{b}$ are constants. The stopped-flow time courses for this step are all single exponential, in accord with Eq. (4). The observed rate constants $\left(\mathrm{k}_{2, \mathrm{obs}}\right)$ are linearly dependent on [OMP] as shown in Fig. 3 and the slope yields $\mathrm{k}_{2}=2.95 \times 10^{4} \mathrm{M}^{-1} \mathrm{~s}^{-1}$.

Rates of regeneration of Mn(III)-MP8 and product formation

The substrate 1-naphthol was used to examine if the rate of regeneration of $\mathrm{Mn}(\mathrm{III})-\mathrm{MP}-8$ (i.e., the $\mathrm{k}_{2}$-step) reflects the substrate reactivity. 1-Naphthol exhibits fluorescence at $465 \mathrm{~nm}$ when excited at $330 \mathrm{~nm}$. In the presence of $\mathrm{Mn}$ (III)-MP8, 1-naphthol is oxidized by $\mathrm{H}_{2} \mathrm{O}_{2}$ to form a non-fluorescent product. The stoppedflow changes in absorbance at $404 \mathrm{~nm}$ and in fluorescence $\left(\lambda_{\mathrm{ex}}=330 \mathrm{~nm}\right)$ upon addition of 1-naphthol to $\underline{1}$ at $\mathrm{pH} 10.7$ are shown in Fig. 4. The disappearance of 1 (Fig. 4a) and 1-naphthol (Fig. 4b) occurs at the same rate within the experimental uncertainty. Thus the rate constant $\left(\mathrm{k}_{2}\right)$ for the regeneration of $\mathrm{Mn}$ (III)-MP8 is a good measure of substrate reactivity. 

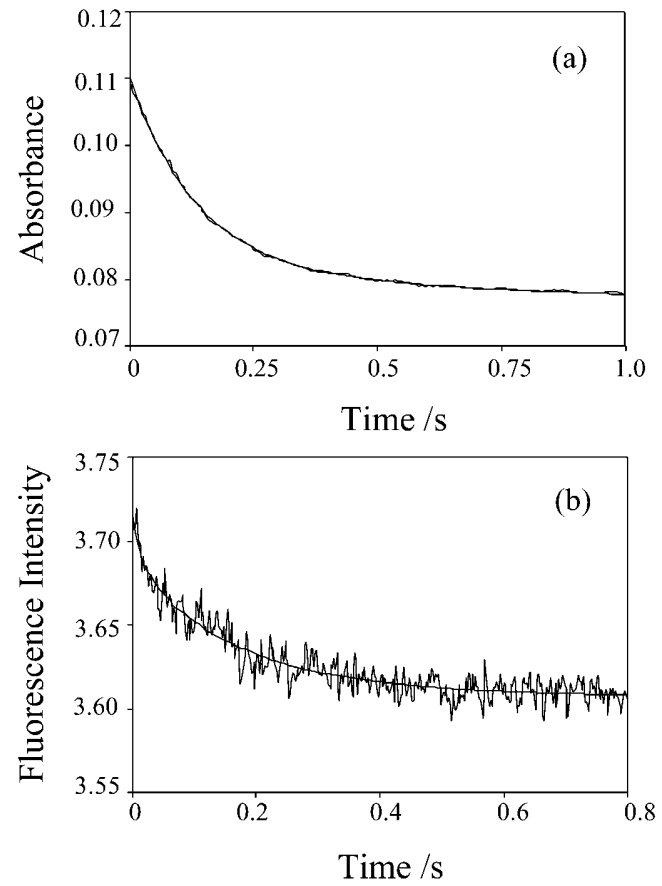

Fig. 4 Time courses for the changes in: a absorbance at $404 \mathrm{~nm}$; b fluorescence $\left(\lambda_{\mathrm{ex}}=330 \mathrm{~nm}\right)$ for the reaction of 1 and 1-naphthol $\left(10 \mu \mathrm{mol} \mathrm{l}^{-1}\right)$ at $\mathrm{pH}$ 10.7. $\mathrm{Mn}(\mathrm{III})-\mathrm{MP} 8\left(10 \mu \mathrm{mol} \mathrm{l}^{-1}\right)$ and $\mathrm{H}_{2} \mathrm{O}_{2}$ $\left(9.8 \mu \mathrm{mol} \mathrm{l}^{-1}\right)$ were premixed for $30 \mathrm{~s}$ and then mixed with 1-naphthol to initiate the regeneration of Mn(III)-MP8

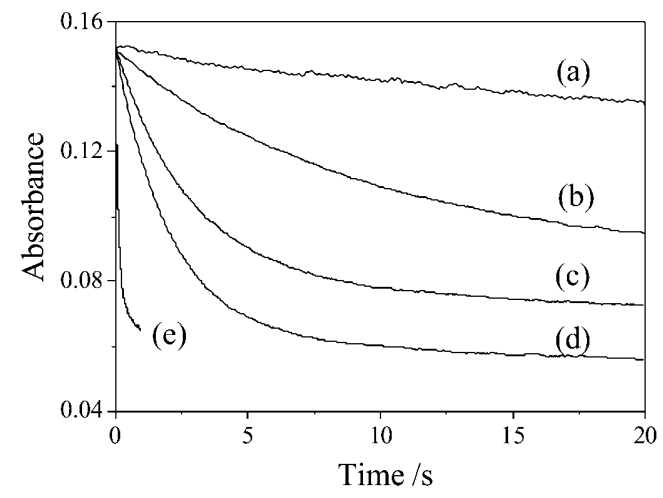

Fig. 5 Time courses for the changes in absorbance at $404 \mathrm{~nm}$ for the reaction of 1 with various substrates at $\mathrm{pH} 10.7$. [Mn(III)MP8] $=4.4 \mu \mathrm{mol}^{-} 1^{-1},\left[\mathrm{H}_{2} \mathrm{O}_{2}\right]=1.96 \mu \mathrm{mol} \mathrm{l^{-1 }}$, and [substrate] $=$ $10 \mu \mathrm{mol} 1^{-1}$. The substrates are: a aniline; b ferrocyanide; $\mathbf{c}$ homovanillic acid; d 4-methoxyphenol; e ascorbic acid

\section{Substrate reactivity}

We have also carried out similar stopped-flow experiments for the reaction of 1 with various other substrates. Different substrates exhibit very different rate for the regeneration of Mn(III)-MP8 as demonstrated in Fig. 5. The values of $\mathrm{k}_{2}$ for various substrates can be determined using the kinetic treatments described above and the results are listed in Table 1 . The values of $k_{2}$ cover more than two orders of magnitude, ranging from $1.04 \times 10^{6} \mathrm{M}^{-1} \mathrm{~s}^{-1}$ for ascorbic acid to $4.61 \times 10^{3} \mathrm{M}^{-1} \mathrm{~s}^{-1}$
Table 1 The rate constants $\mathrm{k}_{2}$ of various substrates at $\mathrm{pH} 10.7$

\begin{tabular}{ll}
\hline Substrates & $\mathrm{k}_{2} / \mathrm{M}^{-1} \mathrm{~s}^{-1}$ \\
\hline Ascorbic acid & $1.04 \times 10^{6}$ \\
1-Naphthol & $6.25 \times 10^{5}$ \\
ABTS & $1.62 \times 10^{5}$ \\
4-Methoxyphenol & $4.71 \times 10^{4}$ \\
Homovanilline acid & $3.36 \times 10^{4}$ \\
$o$-Methoxyphenol & $2.95 \times 10^{4}$ \\
p-Anisidine & $2.36 \times 10^{4}$ \\
Ferrocyanide & $1.08 \times 10^{4}$ \\
Aniline & $4.61 \times 10^{3}$ \\
\hline
\end{tabular}

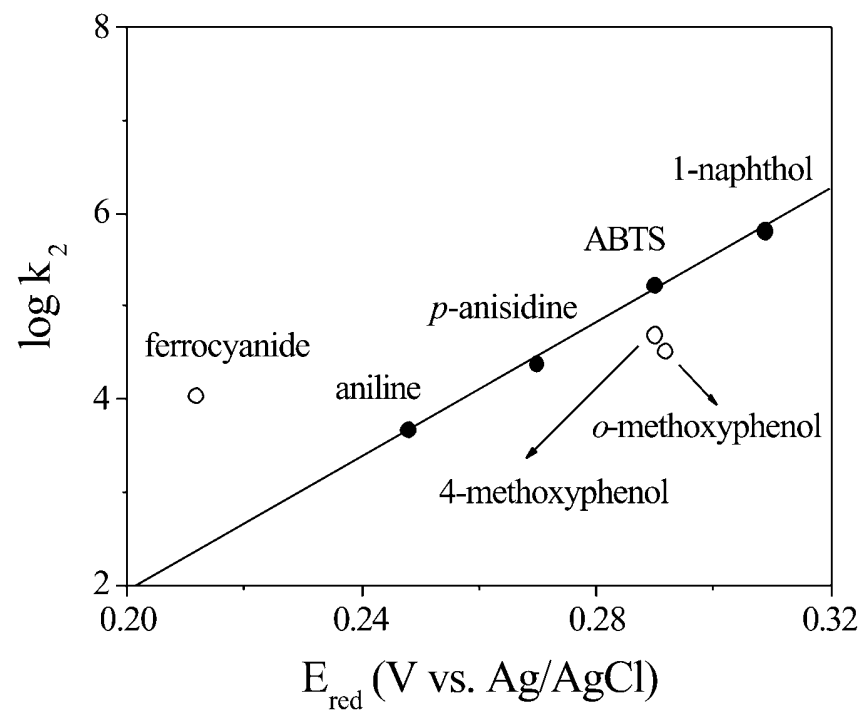

Fig. 6 Plot of $\log \mathrm{k}_{2}$ vs $\mathrm{E}_{\text {red }}$ at $\mathrm{pH}$ 10.7. Linear correlation was observed for several substrates in solid circles

for aniline. The substrate reactivity $\left(\log \mathrm{k}_{2}\right)$ is linearly correlated with its reduction potential as illustrated in Fig. 6. Deviation from the straight line was observed for ferrocyanide, OMP, and 4-methoxyphenol. The substrate reactivity for the system of Mn(III)-MP8 was also compared with that of Fe(III)-MP8 [20] as shown in Fig. 7.

$\mathrm{pH}$ dependence of the rate constants

The stopped-flow experiments for the oxidation of $\mathrm{Mn}$ (III)-MP8 by $\mathrm{H}_{2} \mathrm{O}_{2}$ have also been carried out at various $\mathrm{pH}$. The time courses for the change in absorbance at $404 \mathrm{~nm}$ for the formation of 1 at several $\mathrm{pH}$ values are shown in Fig. 8a. The rate increases dramatically as the $\mathrm{pH}$ increases. The initial rate method was employed to determine the values of $\mathrm{k}_{1}$ at various $\mathrm{pH}$. The plot of $\mathrm{k}_{1} \mathrm{vs} \mathrm{pH}$ is shown in Fig. 8b. The curve is sigmoidal with a $\mathrm{pK}_{\mathrm{a}}$ of 11.90 . No other intermediates were detected in the entire $\mathrm{pH}$ range studied. At high $\mathrm{pH}$ $(\geq 10)$, the traces pass through a maximum and then decrease at longer observation time (data not shown). The decrease in absorbance at $404 \mathrm{~nm}$ is accompanied 


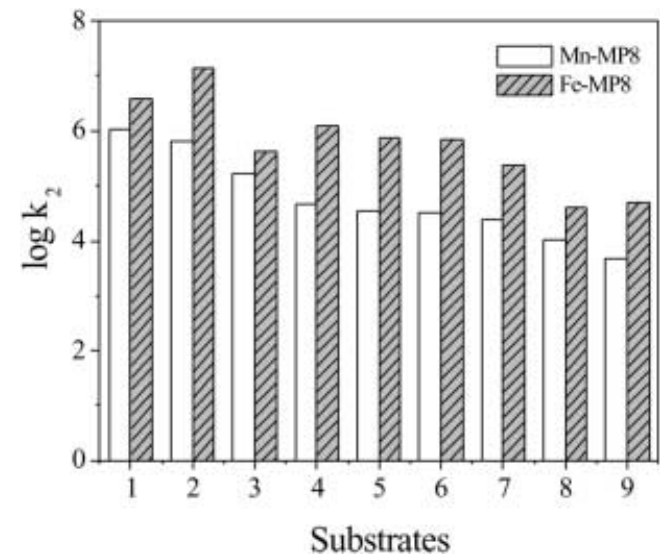

Fig. 7 Comparison of the reactivity $\left(\log \mathrm{k}_{2}\right)$ for various substrates in the Fe(III)- and Mn(III)-MP8 systems
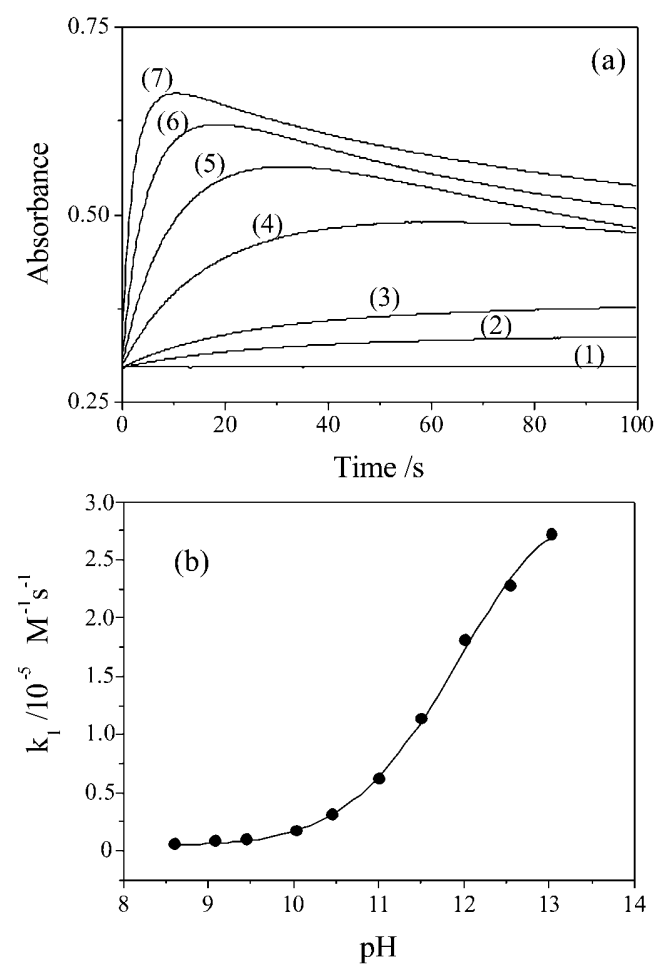

Fig. 8 a Time courses of the changes in absorbance at $404 \mathrm{~nm}$ for the oxidation of $\mathrm{Mn}$ (III)-MP8 $\left(4.2 \mu \mathrm{mol} \mathrm{l}^{-1}\right)$ by $\mathrm{H}_{2} \mathrm{O}_{2}(3.92 \mu \mathrm{mol}$ $1^{-1}$ ) at several pH: (1) 7.98, (2) 8.61, (3) 9.09, (4) 9.46, (5) 10.05, (6) 10.46 , (7) 11.02. b pH-dependence of $\mathrm{k}_{1}$ for the reaction in (a). Fitting of the curve yields a $\mathrm{pK}_{\mathrm{a}}$ of 11.90

by a concomitant increase in absorbance at $368 \mathrm{~nm}$, indicating that a portion of 1 is slowly converted back to $\mathrm{Mn}(\mathrm{III})-\mathrm{MP} 8$ and that the higher the $\mathrm{pH}$, the faster the conversion. We have also determined the rate constant $\mathrm{k}_{2}$ for the regeneration of $\mathrm{Mn}(\mathrm{III})$-MP8 upon addition of OMP at various $\mathrm{pH}$ and the results are shown in Fig. 9. OMP exhibits a maximum reactivity at $\mathrm{pH} \sim 10$. As the $\mathrm{pH}$ increases, the reactivity drops sharply and a sigmoidal fitting of the curve yields a $\mathrm{pK}_{\mathrm{a}}$ of 10.81 . The

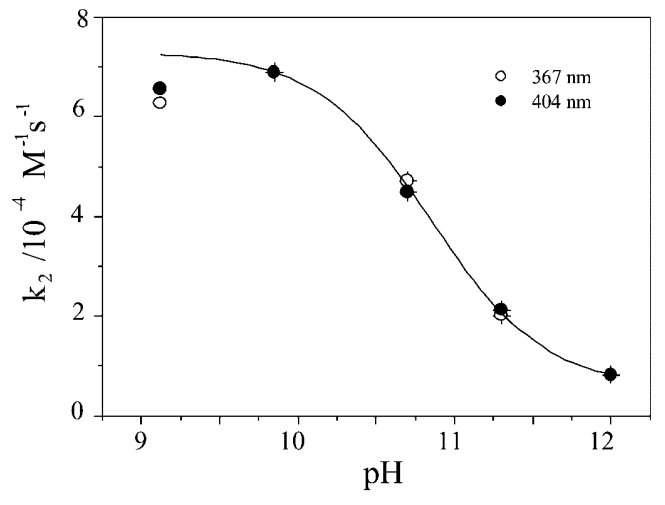

Fig. $9 \mathrm{pH}$-dependence of $\mathrm{k}_{2}$ for the reaction of 1 and OMP. Fitting of the curve yields a $\mathrm{pK}_{\mathrm{a}}$ of 10.81 . Data points at $\mathrm{pH} 9.0$ were not included in the fitting

data points obtained at $368 \mathrm{~nm}$ and $404 \mathrm{~nm}$ fall essentially on the same curve. The formation of 1 was too slow and too little for the substrate reactivity to be determined at $\mathrm{pH}$ below 9 .

Deuterium solvent isotope effect

The deuterium solvent isotope effect is useful for the delineation of whether a proton transfer is involved in the rate-limiting step. We have carried out the stopped-flow experiments for the oxidation of $\mathrm{Fe}(\mathrm{III})-\mathrm{MP} 8$ and $\mathrm{Mn}(\mathrm{III})-\mathrm{MP} 8$ in $\mathrm{H}_{2} \mathrm{O}$ or $\mathrm{D}_{2} \mathrm{O}$ at $\mathrm{pL}(\mathrm{pH}$ or $\mathrm{pD})$ 10.7 and the results are shown in Fig. 10. Single exponential fitting of the stopped-flow traces allows the determination of the rate constants and the relative rate constants yield the deuterium isotope effect. The formation of $\mathrm{O}=\mathrm{Fe}(\mathrm{IV})-\mathrm{MP} 8$ exhibits a prominent deuterium isotope effect $\left(\mathrm{k}_{\mathrm{H}} / \mathrm{k}_{\mathrm{D}}=2.35\right)$, while the formation of 1 shows essentially no isotope effect $\left(\mathrm{k}_{\mathrm{H}} /\right.$ $\left.\mathrm{k}_{\mathrm{D}}=1.08\right)$.

\section{Discussion}

Oxidation of $\mathrm{Mn}$ (III)-MP8 by $\mathrm{H}_{2} \mathrm{O}_{2}$ at $\mathrm{pH} 0.7$ results in the formation of 1 (Fig. 1), whose spectral features resemble those reported for $\mathrm{O}=\mathrm{Mn}(\mathrm{IV})$-MP8 [21]. There are two possible pathways for the formation of 1 , which is one oxidation equivalent above $\mathrm{Mn}$ (III)-MP8. One involves the heterolytic cleavage of the $\mathrm{O}-\mathrm{O}$ bond in the MP-bound peroxide to yield $\mathrm{Mn}(\mathrm{V})-\mathrm{MP} 8$ (or its equivalent) followed by a very fast conversion of this intermediate to 1 . The heterolytic process requires a significant charge separation in the transition state. The other involves a homolytic cleavage of the $\mathrm{O}-\mathrm{O}$ bond in MP-bound peroxide to give $\underline{1}$ directly. This radical-like reaction will largely depend on the type of peroxide used and on the factors that will facilitate the formation of radicals. Monooxygenases and peroxidases generally cleave heterolytically leading to compound I formation 

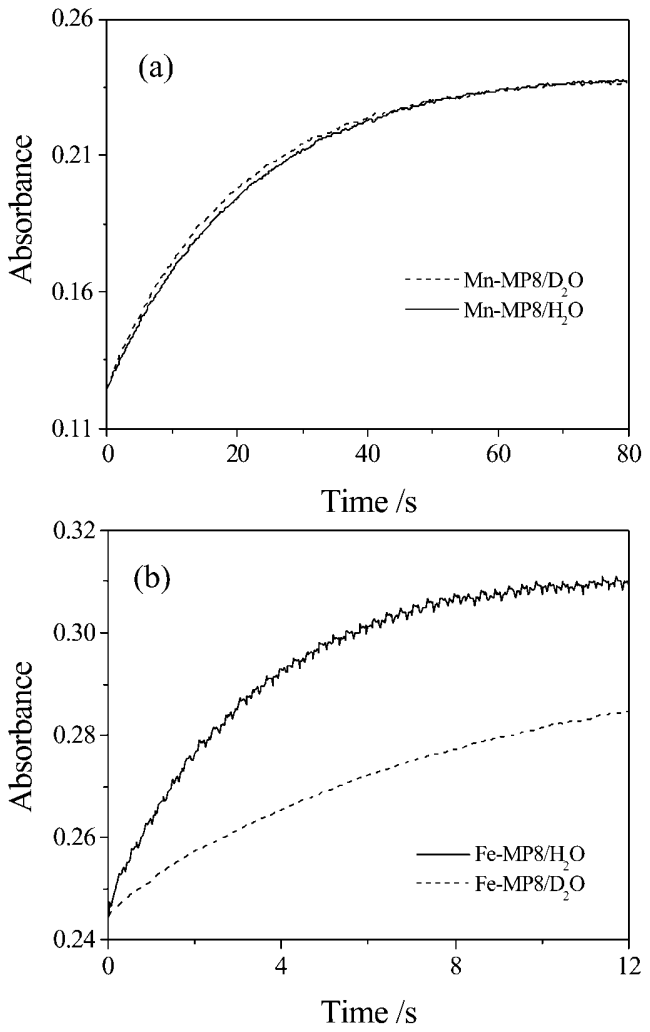

Fig. 10 Time courses for the changes in absorbance for the oxidation of: a $\mathrm{Mn}(\mathrm{III})-\mathrm{MP} 8 \quad\left(4.4 \mu \mathrm{mol} \mathrm{l}^{-1}\right)$; b $\mathrm{Fe}$ (III)-MP8 $\left(4.4 \mu \mathrm{mol} \mathrm{l}{ }^{-1}\right)$ with $\mathrm{H}_{2} \mathrm{O}_{2}\left(1.96 \mu \mathrm{mol} \mathrm{l}^{-1}\right)$ at $\mathrm{pH}(\mathrm{pD})$ 10.7. The reaction was monitored at $404 \mathrm{~nm}$ for Mn(III)-MP8 and $415 \mathrm{~nm}$ for $\mathrm{Fe}(\mathrm{III})-\mathrm{MP} 8$

and globins cleave homolytically leading to compound II formation. Kinetic studies of porphyrin model compounds $[7,24,25]$ have revealed that a proton transfer is involved in the transition state of a heterolytic process but not for a homolytic process, for which the leaving group (i.e., radical) is not a strong base. Thus a significant deuterium solvent isotope effect will be expected for a heterolytic process but not for a homolytic process. A significant deuterium isotope effect $\left(\mathrm{k}_{\mathrm{H}} / \mathrm{k}_{\mathrm{D}}=2.35\right)$ was indeed observed for the formation of $\mathrm{O}=\mathrm{Fe}(\mathrm{IV})$-MP8 suggesting the favoring of a heterolytic process. Deuterium solvent kinetic isotope effects in the region of 2.0 are typical of reactions involving proton transfer [26]. The formation of 1 , however, shows essentially no isotope effect $\left(\mathrm{k}_{\mathrm{H}} / \mathrm{k}_{\mathrm{D}}=1.08\right)$, indicating the favor of a homolytic process.

The rate for the formation of 1 increases sharply (with a $\mathrm{pK}_{\mathrm{a}}$ of 11.90) as the $\mathrm{pH}$ increases (Fig. 8b). This $\mathrm{pK}_{\mathrm{a}}$ is very close to that of free $\mathrm{H}_{2} \mathrm{O}_{2}$ of 11.65 [27]. It has been proposed that MP8-bound hydroperoxide is the active form for the peroxidase reaction [5, 6]. High $\mathrm{pH}$ will increase the amount of $\mathrm{HO}_{2}^{-}$, favoring the formation of MP8-bound $\mathrm{HO}_{2}^{-}$(through $\mathrm{HO}_{2}^{-}+\rightleftarrows$ MP8 $\mathrm{HO}_{2}^{-}-\mathrm{MP8}$ and hence accelerating the formation of 1 . The value of $k_{2}$ for OMP decreases rapidly (with a $\mathrm{pK}_{\mathrm{a}}$ of 10.81) as the $\mathrm{pH}$ increases (Fig. 9). The origin of this deprotonation process is not clear. It may result from changes in redox potentials of 1 and/or OMP as $\mathrm{pH}$ changes. The overall reaction rate is determined by the combination of these two steps $\left(\mathrm{k}_{1}\right.$ and $\left.\mathrm{k}_{2}\right)$, which shows opposite $\mathrm{pH}$-dependence. As a result, a maximum overall rate will exist at certain $\mathrm{pH}$, depending on the substrate used. For OMP, the maximum rate for the formation of product occurs at $\sim \mathrm{pH} 12$ [19].

The reactivity of 1 with various substrates covers more than two orders of magnitude at $\mathrm{pH} 10.7$ (Table 1). It is interesting to note that, for a typical peroxidase reaction reported in the literature with $\left[\mathrm{H}_{2} \mathrm{O}_{2}\right] \sim 0.1 \mathrm{mmoll}^{-1}$ and $[\mathrm{S}] \sim 1 \mathrm{mmol} \mathrm{l}^{-1}$, the rate for the reaction of $\underline{1}$ with the substrate (i.e., $\mathrm{k}_{2}[\mathrm{~S}]$ ) in Table 1 (except aniline and ferrocyanide) is $\sim 1-2$ orders of magnitude greater than that of the formation of 1 (i.e., $\mathrm{k}_{1}\left[\mathrm{H}_{2} \mathrm{O}_{2}\right]$ ) at $\mathrm{pH} 10.7$. Under this circumstance, the formation of 1 becomes rate-limiting and the difference in substrate reactivity will not be distinguished if the reaction is carried out by mixing all the reagents at one time and then following the formation of product. The rate constants $\left(\log \mathrm{k}_{2}\right)$ are linearly correlated with the reduction potentials for most of the substrates studied (Fig. 6). A difference in the reducing power of the substrate exhibits a prominent effect on its reactivity, with the easier oxidized species showing greater reactivity. The linear correlation suggests that an electron transfer process is involved in the rate-limiting step. For a given substrate, the reactivity at $\mathrm{pH} 10.7$ is smaller by 2-25 times for the Mn(III)-MP8 system than for the Fe(III)-MP8 system (Fig. 7). The difference in reactivity may be attributed to a change in the reduction potential of the intermediate when $\mathrm{Fe}$ (III) is replaced by $\mathrm{Mn}$ (III). A decrease in redox potential (II $\rightarrow$ III) by $154 \mathrm{mV}$ was reported for MP8 upon substitution of $\mathrm{Fe}$ with $\mathrm{Mn}$ [19]. It is also noted in Fig. 7 that ascorbic acid exhibits much greater reactivity than most of the substrates examined (except for the 1-naphthol/Fe(III)-MP8 system). Ascorbic acid was normally employed to abolish the peroxidase reaction for a successful observation of the P450-type reaction of Fe(III)-MP8 [9, 10]. Evidently it is very efficient in inhibiting the peroxidase reaction for other substrates. However, once the intermediate has reacted with ascorbic acid, it will not be able to induce the P450 reaction for other substrates. Therefore there must exist some other reactive species responsible for the P450 reaction.

Acknowledgement We thank the National Science Council of ROC for the financial support of this research (NSC 89-2113-M-002-057).

\section{References}

1. Ortiz de Montellano PR (1987) Acc Chem Res 20:289-294

2. Sheldon RA (ed) (1994) Metalloporphyrins in catalytic oxidation. Marcel Dekker, New York

3. Montanari F, Casella L (ed) (1994) Metalloporphyrin catalyzed-oxidations. Kluwer, Dordrecht, The Netherlands

4. Aron J, Baldwin DA, Marques MM, Pratt JM, Adams PA (1983) J Inorg Biochem 27:227-243 
5. Bavid DA, Marques HM, Pratt JM (1985) FEBS Lett 183: 309-312

6. Baldwin DA, Marques HM, Pratt JM (1987) J Inorg Biochem 30:203-217

7. Adams PA (1990) J Chem Soc Perkin Trans 2 1407-1414

8. Cunningham ID, Snare GR (1992) J Chem Soc Perkin Trans 2 2019-2023

9. Adams PA, De Milton RC, Silver J (1994) Biometals 7:217-220

10. Spee JH, Boersma MG, Veeger C, Samyn B, Van Beeumen J, Warmerdam G, Canters GW, Van Dongen WMAM, Rietjens IMCM (1996) Eur J Biochem 241:215-220

11. Osman AM, Boeren S, Boersma MG, Veeger C, Rietjens IMCM (1997) Proc Nat Acad Sci USA 94:4295-4299

12. Osman AM, Boeren S, Veeger C, Rietjens IMCM (1997) Chem-Biol Interact 104:147-164

13. Aron J, Baldwin DA, Marques HM, Pratt AM, Adams PA (1986) J Inorg Biochem 27:227-243

14. Wang J-S, Van Wart HE (1989) J Phys Chem 93:7925-7931

15. Wang J-S, Back HK, Van Wart HE (1991) Biochem Biophys Res Commun 179:1320-1324
16. O'Carra P (9175) In: Smith KM (ed) Porphyrins and metalloporphyrins. Elsevier, New York, pp 124-153

17. Yonrysni Y, Asakura T (1969) J Biol Chem 244:4580-4588

18. Gelb MH, Toscano WA, Sligar SG (1982) Proc Nat Acad Sci USA 79:5758-5762

19. Primus JL, Boersma MG, Mandon D, Voeren S, Veeger C, Weiss R, Rietjens IM (1999) J Biol Inorg Chem 4:274-283

20. Yeh H-C, Wang J-S, Su YO, Lin W-Y (2001) J Biol Inorg Biochem (in press)

21. Low DW, Abedin S, Yang G, Winkler JR, Gray HB (1998) Inorg Chem 37:1841-1843

22. Glasoe PK, Long FA (1960) J Phys Chem 64:188-191

23. Jeng W-Y, Chang Y-D, Chuang W-J (2001) J Inorg Biochem (in press)

24. Gopinath E, Bruice TC (1991) J Am Chem Soc 113:6090-6094

25. Bruice TC (1991) Acc Chem Res 24:243-249

26. Traylor TG, Xu F (1990) J Am Chem Soc 112:178-186

27. Dean JA (1985) Lange's handbook of chemistry, 13th edn. McGraw-Hill, New York, p 5-15 